\title{
Global economy interacts with climate change to jeopardize species conservation: the case of the greater flamingo in the Mediterranean and West Africa
}

The conservation of many species depends on sustainable economic activities which shape their habitats. The economic use of these anthropogenic habitats may change quickly due to world trade globalization, market reorientations, price volatility or shifts in subsidy policies (Gauthier et al. 2005; Gottschalk et al. 2007). Recently, the finance crisis has impacted economy worldwide. How this may have affected the use of habitats beneficial to biodiversity has not been documented so far. However, consequences could be particularly acute for species sensitive to climate change while jeopardizing long-term conservation efforts. We illustrate this concern using the case of the greater flamingo Phoenicopterus roseus in the Mediterranean and West Africa.

Flamingos are long-lived colonial waterbirds inhabiting coastal brackish wetlands and salt lakes around the world. Breeding colonies are dependent on both rainfall and availability of undisturbed islands to protect eggs and chicks from terrestrial predators (Simmons 1996; Johnson \& Cézilly 2007). Saltpans have been exploited by flamingos because the circulation of brine over extensive areas guarantees favourable water levels and salinities annually (Johnson \& Cézilly 2007; Béchet et al. 2009).

In the south of the Mediterranean, most colonies of greater flamingos occur in natural wetlands facing the challenge of hydrological stochasticity (Fig. 1). Breeding is intermittent depending on minimum thresholds of precipitation and given scarce rainfall, the average probability of successful breeding in a given year at these sites is only 0.44 ( $n=6$ colonies; $95 \%$ confidence interval (CI): 0.35-0.52). The low rate of successful breeding in the south of the Mediterranean may further decrease in future years due to predicted dryer conditions (Bates et al. 2008). This should reduce flooding frequency of favourable wetlands by more episodic rainfall and in turn curtail fewer breeding opportunities for flamingos.

In the north of the Mediterranean, brackish wetlands have often been transformed into saltpans and/or fish farms which buffer hydrological stochasticity. In particular, the Mediterranean coastline comprises $>170$ saltpans (range 112000 ha) spread over 18 countries (Sadoul et al. 1998). Throughout this region, most flamingo colonies are located in saltpans which represent $45 \%$ of the breeding sites of the Mediterranean and West African population (Fig. 1). The probability of successful breeding in saltpans, $0.83(n=7$ colonies; 95\% CI: $0.66-0.93$ ), is $1.86 \pm 0.31$ times higher than in natural habitats (logistic GLM, $\mathrm{df}=235, p<0.001$ ).
Saltpans contributed to $46 \%$ of the chicks fledged in the last five years in the Mediterranean and West Africa.

In 2007, financial changes disrupted the economy of the saltpans of Salin-de-Giraud in the Camargue (Rhône delta, France), the largest commercial saltpans in Europe (12 000 ha), causing flamingos to fail to breed at one of their main colonies in the world. It was the first interruption in annual breeding since 1974. In the 1960s, the Mediterranean population of greater flamingos was only half of what it is today, and breeding occurred at only two sites, the Camargue and Fuente de Piedra (Spain). Poor breeding success was linked to low rainfall in Spain and the lack of suitable nesting sites in the Camargue. In order to solve this latter problem, an artificial island was built in the Fangassier lagoon in the saltpans of Salin-de-Giraud. Flamingos adopted this island in 1974, and bred there annually until 2007.

In 2007, Salins Group, the owner of the lagoon, decided to decrease salt production by $60 \%$, reduce its employees by $50 \%$ and sell $20 \%$ of its estate, including the Fangassier lagoon. This decision triggered a social conflict and a strike that prevented the traditional flooding of the lagoon. In the absence of water, the birds did not breed. The decision to reduce salt production resulted from cascading events of acquisitions and sales, moving the capital from managers of industry to financial investors. Salins Group was bought out twice between 1997 and 2000, and returned to its original managers through two successive leverage buy outs (LBO), in 2000 and 2004. LBOs are financial operations facilitating the purchase of firms by financial groups, financing an important share of the cost of acquisition by debt. Typically, LBOs increase the debt by 5-8 times, and the firm's turnover is used to reimburse this debt. As a result, there are layoffs and reductions in mid-term investments to rapidly reimburse high-interest loans (Bruton et al. 1999; World Economic Forum 2008; Nielsen 2008; Hall 2008). In 2006, the chemical company Arkema, who purchased $40 \%$ of the Salins Group's annual production, breached its contract following a technical innovation disposing of its need for salt. This imperilled the reimbursement of Salins Group's debt, causing financial distress and triggering land sales. In 2009, following the 2008 world financial crisis, Salins Group put 9000 ha of saltpans up for sale and announced a new dismissal plan.

The closure of $45 \%$ of the Mediterranean saltpans in the $1990 \mathrm{~s}$ was restricted to small-scale entities (Paracuellos et al. 2002), but this is no longer the case. Even the largest saltpans 
Figure 1 Greater flamingo breeding sites in the Mediterranean and West Africa. Colony sites were classified as active commercial saltpans (O), abandoned saltpans ( $\square$ ) or natural wetlands (O) based on Johnson \& Cézilly (2007). Symbol size is proportional to colony productivity index, calculated as the sum of chicks fledged over the last five years with successful breeding (except in Algeria for which breeding occurred only twice and Tunisia only four times). Chicks were counted from the ground or from aerial photographs depending on sites. In brackets is the average probability of breeding success for a given colony in a given year.

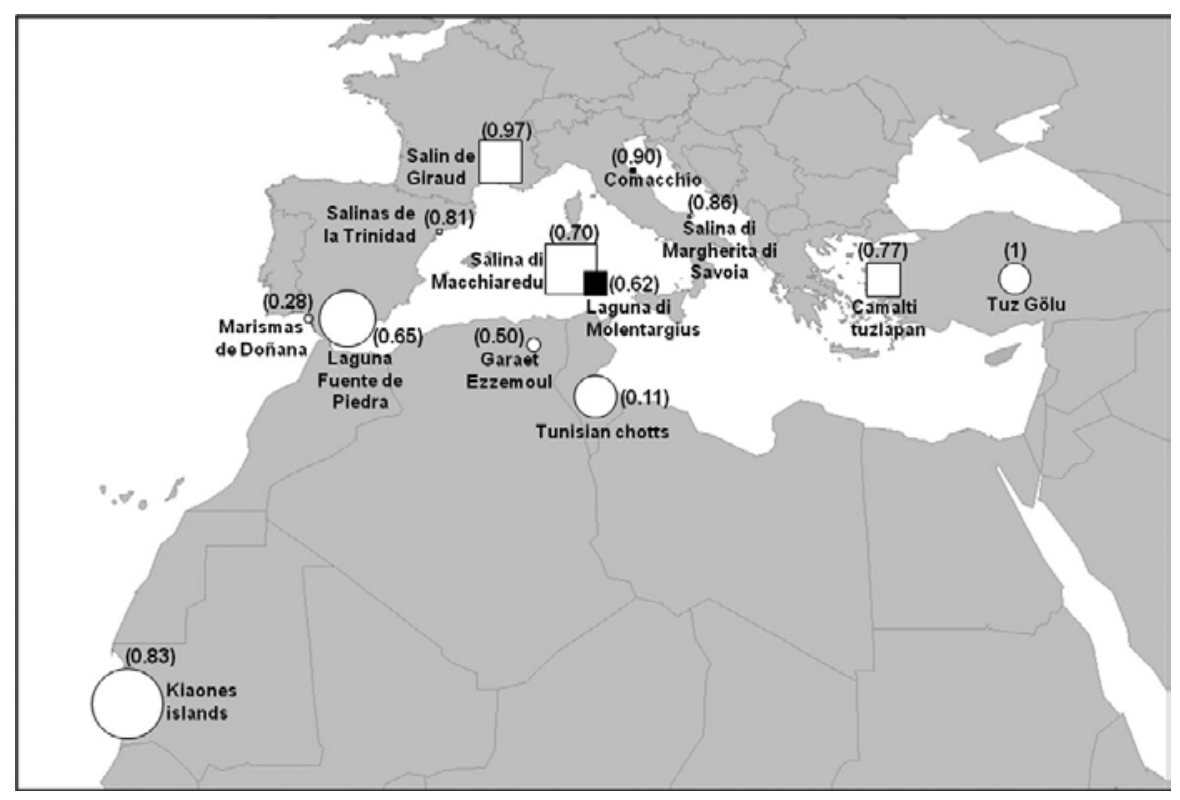

are sensitive to global financial conditions. Since saltpans provide up to $50 \%$ of flamingos foraging requirements during the breeding season (Béchet et al. 2009), this species will obviously be affected by such economically-driven changes. Saltpans buffer rainfall variability, thus allowing annual reproduction of flamingos (Béchet \& Johnson 2008; Béchet et al. 2009). The closure of saltpans may thus enhance the adverse effects on flamingos and other waterbirds of predicted reductions in precipitation (Bates et al. 2008) by limiting the availability of alternative nesting sites. As flamingos of the Mediterranean belong to a metapopulation, local changes could affect the species at a much larger scale (Balkız et al. 2010). Finally, the sea level rise predicted for the Mediterranean (Bates et al. 2008) may constitute an additional threat, flooding existing breeding sites (for example the submersion of the Ebro delta; Rovira \& Ibàñez 2007).

Increasingly, global economy stochasticity directly affects land use, with important negative consequences for wildlife (Robertson \& Van Schaik 2001; Gauthier et al. 2005; Gottschalk et al. 2007). Here, we additionally show that financial agendas can disrupt a conservation success story, which relied on pursuing a sustainable economic industry: solar saltpans. Global finance could thus exacerbate negative effects of climate change by affecting anthopogenic habitats acting as biodiversity refuges. We call for large-scale monitoring of the effects on species conservation of this new type of stochasticity imposed by financial volatility in the global economy. This requires multi-case analyses by interdisciplinary teams, including economists and ecologists. Fighting for regulations that would divert financial volatility from sustainable economic activities, thus favouring longterm stable sources of funding for such activities, should become a top-ranking priority of conservation agendas.

\section{Acknowledgements}

We thank the Greater Flamingo Network for providing counts and Salins Group for granting access to Salin-de-Giraud. From 2005, flamingo data from the Camargue are property of Salins Group, Tour du Valat and Réserve Nationale de Camargue.

\section{References}

Balkız, Ö., Béchet, A., Rouan, L., Choquet, R., Germain, C., Amat, J.A., Rendón-Martos, M., Baccetti, N., Nissardi, S., Özesmi, U. \& Pradel, R. (2010) Experience-dependent natal philopatry of breeding greater flamingos. Journal of Animal Ecology 79: 10451056.

Bates, B.C., Kundzewicz, Z.W., Wu, S. \& Palutikof, J.P. (2008) Climate Change and Water. Geneva, Switzerland: IPCC Secretariat.

Béchet, A., Germain, C., Sandoz, A., Hirons, G.J.M., Green, R.E., Walmsley, J.G. \& Johnson, A.R. (2009) Assessment of the impacts of hydrological fluctuations and salt pans abandonment on greater flamingos in the Camargue, south of France. Biodiversity and Conservation 18: 1575-1588.

Béchet, A. \& Johnson, A.R. (2008) Anthropogenic and environmental determinants of greater flamingo Phoenicopterus roseus breeding numbers and productivity in the Camargue (Rhone delta, southern France). Ibis 150: 69-79.

Bruton, J.D., Keels, J.K. \& Scifres, E. (1999) The ethics of the complete management buyout cycle: a multi-perspective analysis. Journal of Business Ethics 19: 403-413.

Gauthier, G., Giroux, J.F., Reed, A., Béchet, A. \& Belanger, L. (2005) Interactions between land use, habitat use and population increase in greater snow geese: what are the consequences for natural wetlands? Global Change Biology 11: 856-868.

Gottschalk, T., Diekötter, T., Ekschmitt, K., Weinmann, B., Kuhlmann, F., Purtauf, T., Dauber, J. \& Wolters, V. (2007) 
Impact of agricultural subsidies on biodiversity at the landscape level. Landscape Ecology 22: 643-656.

Hall, D. (2008) Private equity and employment: the Davos/WEF/Harvard study. Technical report. Public Services International Research Unit (PSIRU), London, UK [www document]. URL http://www.psiru.org/reports/2008-02-PEWEF.doc

Johnson, A.R. \& Cézilly, F. (2007) The Greater Flamingo. London, UK: T \& AD Poyser.

Nielsen, R.P. (2008) The private equity-leveraged buyout form of finance capitalism: ethical and social issues, and potential reforms. Business Ethics Quarterly 18: 379-404.

Paracuellos, M., Castro, H., Nevado, J.C., Ona, J.A., Matamala, J.J., García, L. \& Salas, G. (2002) Repercussions of the abandonment of mediterranean saltpans on waterbird communities. Waterbirds 25: 492-498.

Robertson, J.M.Y. \& Van Schaik, C.P. (2001) Causal factors underlying the dramatic decline of the Sumatran orang-utan. Oryx 35: 26-38.

Rovira, A. \& Ibàñez, C. (2007) Sediment management options for the lower Ebro River and its delta. Journal of Soils and Sediments 7: 285-295.

Sadoul, N., Walmsley, J. \& Charpentier, B. (1998) Salinas and Nature Conservation. Conservation of Mediterreanean Wetlands No. 9, Series Editors J. Skinner \& A.J. Crivelli. Arles, France: Station Biologique de la Tour du Valat.
Simmons, R.E. (1996) Population declines, viable breeding areas, and management options for flamingos in southern Africa. Conservation Biology 10: 504-514.

World Economic Forum (2008) The global economic impact of private equity report 2008. Globalization of alternative investments. Working papers volume 1. The World Economic Forum, Geneva (Switzerland) \& World Economic Forum USA, New York, USA.

ARNAUD BÉCHET ${ }^{* 1}$, MANUEL RENDÓN-MARTOS ${ }^{2}$, MIGUEL ÁNGEL RENDÓN ${ }^{3}$,

JUAN AGUILAR AMAT ${ }^{3}$, ALAN R. JOHNSON ${ }^{4}$ AND

MICHEL GAUTHIER-CLERC ${ }^{1}$

${ }^{1}$ Centre de Recherche de la Tour du Valat, Le Sambuc, 13200 Arles, France

${ }^{2}$ Reserva Natural de Fuente de Piedra, Junta de Andalucía, Apartado de correos 1, 29520 Fuente de Piedra, Malaga, Spain ${ }^{3}$ Estación Biologica de Doñana, CSIC, Calle Américo Vespucio $s / n, 41092$ Sevilla, Spain

${ }^{4}$ Ancienne poste, Route de l'Eglise, Le Sambuc, 13200 Arles, France

* Correspondence: Dr A. Béchet Tel: +33 490972973 Fax: +33 4 90972019 e-mail: bechet@tourduvalat.org 